\title{
CONCEPTS OF MANAGING AND INCREASING THE EFFICIENCY OF USING AIRSPACE IN RELATION TO INCREASING AIR TRAFFIC
}

\author{
Jarosław KOZUBA, Assoc. Prof. \\ j.kozuba@wsosp.pl \\ Jacek KRAWCZYK, MSc \\ jac.krawczyk@ron.mil.pl
}

\begin{abstract}
Polish airspace is available on equal terms to all its users. Due to the increasing air traffic airspace structure and the system of airspace, management should constantly improve, taking into account the provisions of international and national conditions. The article looks at issues in the management of airspace in order to increase the efficiency of the use of Polish airspace while maintaining an appropriate level of air traffic safety during flight operations by military and civilian aircraft.
\end{abstract}

Keywords: Polish airspace, AAR, corridors in airspace, increasing the efficiency of use of airspace, air operations

\section{Admission}

The border of the Republic of Poland is a vertical surface passing through the border line separating the territory of the Polish state from the territory of other states and from the sea. The boundary of the country also divides the air, water and interior space.

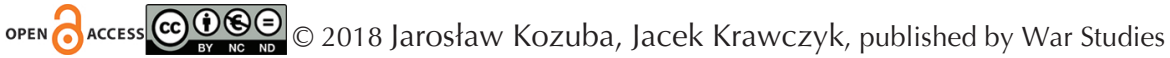
University, Poland

This work is licensed under the Creative Commons Attribution-NonCommercial-NoDerivatives 4.0 License. 
The course of the state border on land and the demarcation of the internal waters and territorial sea with the neighbouring countries are defined in international agreements concluded by the Republic of Poland. The state boundary at sea runs 12 nautical miles from the baseline defined in separate regulations or outside the red boundary into the territorial sea.

The Republic of Poland keeps sovereignty over the land territory and the interior of the land beneath it, the inland waters and the territorial sea, and the bottom and interior of the land beneath them, as well as in the airspace above land territory, inland waters and in the territorial sea. Air Traffic Management, which includes airspace management systems, air traffic flow management and air traffic management, is managed by the Polish Air Navigation Services Agency.

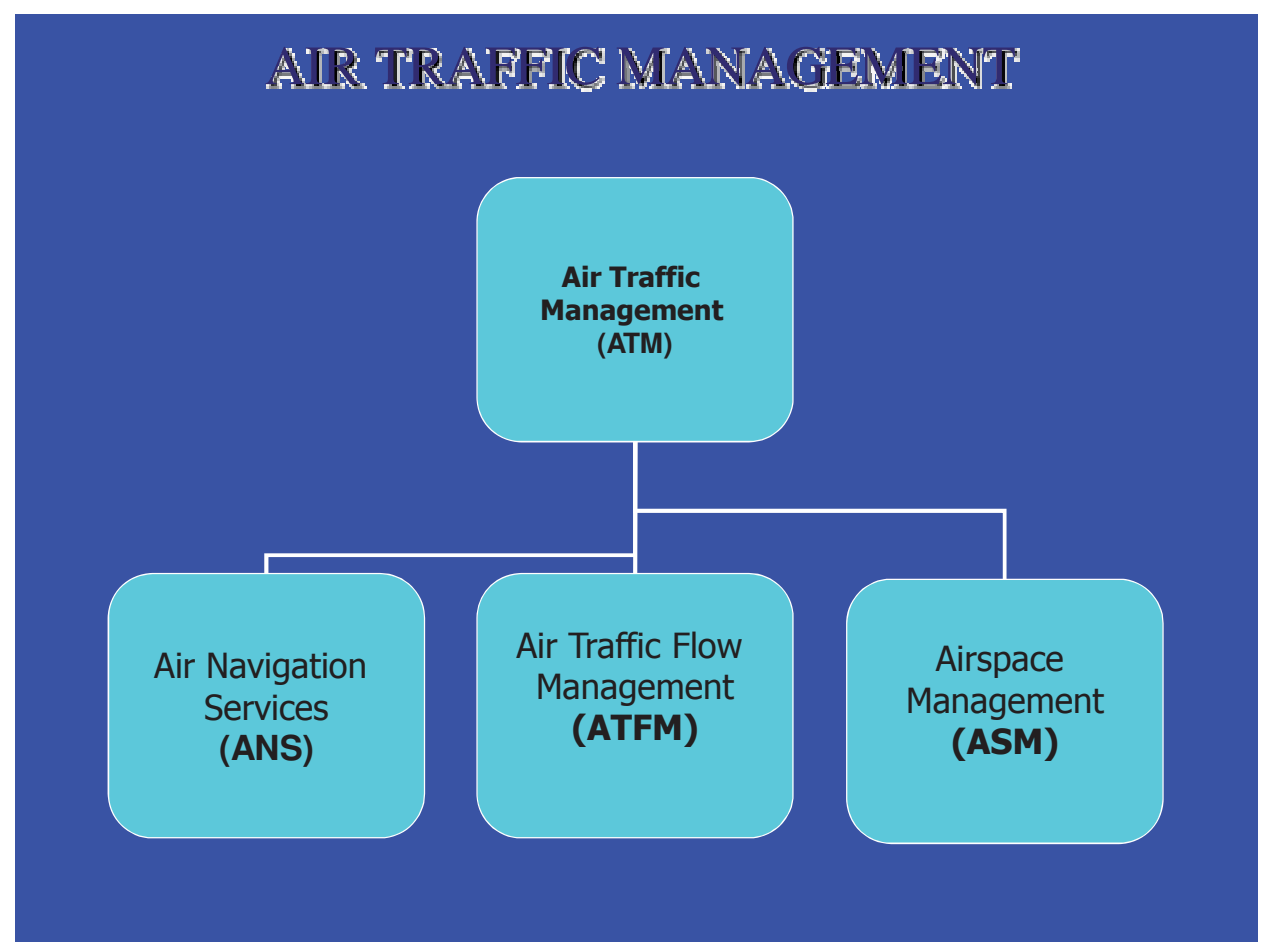

Fig. 1 Air traffic Management System in Polish Airspace (Ustawa z dnia 23 lipca DzU z 2002 r., poz 1112); Annex 2 to the Convention on International Civil Aviation. Air Traffic Regulations; Annex 11 to the Convention on International Civil Aviation. Air Traffic Services) 
The Air Traffic Management system in Polish Airspace cooperates closely with the Polish army. The civil and military services cooperate in the field of operational situation in the airspace.

\section{Joint air traffic management system}

The airspace at FIR Warsaw has been designated from ground or water to FL $660^{1}$, which includes the Polish state border and the Baltic Sea airspace allocated to Poland by EUROCONTROL to provide air traffic services. The composition of Polish airspace includes: airspace controlled and uncontrolled and unclassified airspace.

In unclassified airspace structures (except $\mathrm{MATZ}^{2}$ ), responsible responsibility for the security and command of operations are lies with the organiser or appropriate territorial command of the Armed Forces of the Republic of Poland included including a Control and Reporting Centre. These units secure the command of military aircraft at the tactical level in unclassified airspace structures.

Preparation and protection of training, and exercises and training requires the protection of the necessary airspace parameters, which are prepared at the strategic, pre-tactical and tactical level of airspace management. Currently, the management of airspace at all 3 levels is responsible for the organisational units of the Headquarters of the Polish Armed Forces Air Service (MATSO) and the Polish Air Navigation Services Agency (PANSA).

Planning of aviation projects at the strategic level for military aviation is carried out by the MATSO of the Polish Armed Forces and afterwards the proposal, the introduction of restrictions (in the airspace) in which air training will be carried out, is sent to the Strategic Planning Centre of the Polish Air Navigation Services Agency (SPC PANSA). Polish airspace is available for all users on equal terms. Airspace management is handled by SPC PANSA, which makes it possible for state aviation, general aviation and air lines to carry out aviation projects. Navigation

1 Fl 660 - Flight Level - $20000 \mathrm{~m}$ at medium altitude sea level.

2 MATZ (Military ATZ) - Military Air Traffic Zone. 
fees for providing air traffic services are charged by EUROCONTROL and are the main source of PANSA income.

The above situation does not allow the position of the SPC PANSA to be considered as a priority, as the priority is to secure airspace for aviation. What in the process of airspace management at strategic level leads to the limitations of airspace allocation for state aviation and general aviation. Therefore, it is essential that airspace management at the strategic level takes place in an independent unit in which the duties of the Ministry of National Defence, the Ministry of the Interior and the Minister responsible for transport are performed by the Ministry. The introduction of the aforementioned solution will allow impartial management of Polish airspace, the optimal use of airspace, raise the level of security in the airspace, and clearly divide the tasks of the services and persons without external pressure and increase confidence in Poland on the international scene.

\section{Organization civil aviation authority}

The Ministry of National Defence plans to organise a joint government authority for military aviation, which will shorten the decision-making process and more effectively coordinate action, taking into account the interests of military aviation. The competence of the appointed state aviation authority will coincide with the area of responsibility of the Civil Aviation Authority (CAA) and it is justified that the organisational system of the appointed authority coincides with that of the CAA departments.

Priority areas of activity of the state aviation authority will include:

1. Airspace (politics, air traffic safety, regulations).

2. Qualification of Air Staff.

3. Aircraft registry.

4. Aviation airport facilities record.

5. Military aerodrome registry.

6. Landing and other places of takeoff and landing.

7. Operation and equipment of aerodromes.

8. Laws in the area of air traffic organisation in the classified and unclassified airspace. 
9. Flight Safety Management and Aviation Accidents and Incidents.

10. International Flights.

11. Certification.

12. Unmanned aircraft system.

13. Supervision of all elements of the military aviation management system.

(Ustawa z dnia 3 lipca 2002 r. - Prawo lotnicze)

Taking into account the organisation of the military aviation authority, which does not provide elements of the airspace management system in its area of responsibility, it is necessary to include the airspace management system in question in the area of responsibility of this organisational unit, which will independently manage the air space comprising representatives of users of Polish airspace.

The priority areas of the airspace management units at the strategic level of the organised unit will be:

1. Participation in the planning, organisation and safeguarding of exercises involving the aviation of the Armed Forces of the Republic of Poland and other military aviation on a strategic level (in cooperation with CAA / PANSA).

2. Cooperation with PANS in the sphere of airspace allocation for the purpose of securing the ongoing training of the Armed Forces of the Republic of Poland (introduction of air traffic airspace limited, priority use of TSA zones and other airspace structures, parachute protection, atmospheric probes, etc.) and air shows.

3. Providing flexible management to Polish air space by:

A) The round the clock designated staff at the Centre for Management of Airspace of the Polish Air Navigation Services Agency;

B) Analysing flight requirements and making decisions on the allocation of flexible airspace elements needed to carry out tasks at pre-tactical and tactical levels;

C) Monitoring the use of allocated flexible airspace elements;

4. Cooperation with the operational services of types of Armed Forces regarding the field of use of Polish airspace;

5. Monitor working compliance with air traffic rules in FIR Warsaw; 
6. Planning, setting up, reconciling and modifying airspace structures $\left(\mathrm{MRT}^{3}\right.$,

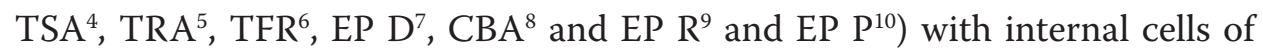
MND and PANSA and CAA;

7. Participate in the work of international committees and working groups.

\section{Ways to increase the efficiency of airspace use}

In recent years, there has been a sharp increase the amount of air traffic in European airspace. It is forecast that by 2025, the flow of air traffic over the territory of the Republic of Poland will double. In order to optimise the use of airspace, the Single European Sky (SES) concept was created.

The SES concept obliges Member States to harmonise air traffic rules and space structures of all European countries. It seems fair that all European countries have identical airspace structures, which will allow for a vertically international sector rather than national airspace distribution. This will contribute to ensuring optimum use of European airspace.

\section{Reorganization of TSA and TRA zones}

With the economic growth of Europe and Poland, there are a growing number of low-altitude flights in FIR Warsaw. This is facilitated by the central geographical position of Poland in Europe. The present configuration of airspace structures does not allow full use of airspace structures. The dynamic development of civil air traffic forces Polish airspace managers to use it flexibly.

3 Military Air Routes Temporary.

4 Temporary Segregated Area.

5 Temporary Reserved Area.

6 flight between Areas.

7 Danger Area.

8 Cross Border Area.

9 Restricted Area.

10 Prohibited Area. 
Accordingly, in order to increase the efficiency of the use of the Polish airspace, the present airspace structures should be adapted to the current needs of civil and military aviation and integrated into the airspace structures of neighbouring countries.

Given the analysis of the use of airspace, it is important to note that the reduction of the level of flexibility in the use of Polish airspace is strongly influenced by the need to secure the country's defence. Through military operations in areas of the airspace such as TSA, flight routes to TSA or TRA and flights between these zones (TFR), Military Air Routes (MRT), air traffic is reduced. TSA, due to their spatial configuration, has the greatest impact on reducing the efficiency of the use of Polish airspace, functioning as closed airspace blocks for aircraft not participating in the exercise.

The current structure of TSA and MRT significantly contributes to reducing the efficiency of airspace use. After analysing the most frequently used airspace, it should be noted that low-altitude civil air routes repeat themselves. The most commonly used height is 300-900 m AGL.

It is reasonable to raise the above- MRT and TSA locations up to 900-1200 m AGL. For air traffic organisers, this will have no impact on the rest of the airspace users It will greatly help to shorten the flight route. For this purpose, TSA should be broken down into smaller segments, taking into account the needs of both the organisers and the flyers under the increased segment of aircraft. The differentiation of upper TSA levels should also be taken into account. Aircraft flight between the higher active TSA segments will greatly contribute to the flexibility of airspace. However, the structures in question must be able to be used within the maximum range from GND to the highest segment height, at specified intervals.

Based on the analysis of the use of unclassified airspace, it is necessary to identify new TSA structures. The new TSA must be larger than the current ones, so that they take into account the ability to collaborate with several concurrent users. Newly organised TSAs should have ranges in their structure, access to the sea (constant or two TSAs must be from GND, and should be in one MTMA (controlled area of military airport or military airport junction) and have full radiolocation coverage. In addition, they should be used by aviation operators operating at cruising speeds 
of up to $250 \mathrm{kts}$ and at higher speeds, to a large extent facilitating joint operations by military aviation and the use of alternate aerodromes.

This project will allow for additional airspace, which is essential for civil aviation and is currently ineffective for military aviation. The space thus obtained will allow for the organisation of new classified airspace structures.

The structure of TSA from a cartographic point of view is simple, but from a practical point of view, TSA does not meet real needs. TSA marginal spaces are not used in the implementation of aeronautical projects. Military aeronautical training is performed with separation at the TSA boundaries and the inability of the aircraft to reach the extreme position of the structure in which it performs the task. It is reasonable to "cut" a few extreme vertexes or round elliptic TSA.

When planning new TSAs and MRTs, attention should be paid to the distribution of zones and airports in neighbouring countries. Once the new airspace structures are planned, the military organiser will be able to accommodate the air structures of neighbouring countries for their needs. This will allow the exercise of some aviation tasks in the airspace of neighbouring countries and will contribute to the same density of common airspace according to Single European Sky and Flexible Used Airspace (FUA) programmes.

The organisation of new structures should include the airspace that was created for single-use projects such as BALTOPS or RAMSTAIN GUARD. These exercises are repeatable each year at the same time and space intervals. Consequently, there is a need to publish created structures as TSA so that they can be used without the need to publish exercises in the form of Supplement to AIP POLAND.

\section{Corridors through TSA}

In order to increase the flexibility of the use of airspace, it is necessary to sort out the "corridors" (sectionalised airspace from the unclassified space in which the air traffic control services will be provided by PANSA staff) through the unclassified portion of the TSA airspace. Aircraft flying through the "corridor" through active TSAs will maintain radio communications with civil air traffic controllers. This is necessary because of the lack of licensed air traffic services in the unclassified 
airspace in accordance with the Aviation Law. Lack of licensed military personnel reduces the level of security in the airspace managed by military services and contributes to reducing the efficiency of the use of "flexible" unclassified airspace.

The dedicated "corridors" should be included in the AIP Poland" time levels will be reported to AMC Poland and published in the AUP ${ }^{12}$ Airspace Use Plan. Changes can be made 3 hours before the scheduled time of activity of the dedicated "corridor". The dedicated "corridor" during a civil aircraft flight will be an integral part of the controlled space. The inlet and outlet of the "corridor" can only take place from / to the controlled space after the submission of the Flight Plan. The flight of the aircraft through the space must be performed in accordance with IFR flight rules.

Transit routes through corridors can also be managed dynamically, as they were previously assigned to the UUP ${ }^{13}$ by AMC POLSKA staff after receiving information from the flight training organiser that it is possible to use the corridor without collision.

An analysis of aircraft flights over the territory of the Republic of Poland indicates that the optimum altitude for international flights is between 8000-12000 metres AGL and for domestic flights 5000-6000m AGL. Consequently, "corridors" should be planned at these height ranges or in conditional airways that are closed due to military air traffic activity in unclassified airspace structures. It will be possible to use both planned flights and bypass dangerous atmospheric phenomena in the corridors.

In order to ensure safety during corridor activity, the Air Force Information Officers (or Navigators) should be organised in the Control and Reporting Centre. This will make a significant contribution to improving the safety of flying aircraft and the flexibility of airspace.

11 Aeronautical Information Publication.

12 Airspace Use Plan.

13 Updated Use Plan. 


\section{Air Refuelling (AAR)}

Another issue related to increasing the efficiency of airspace use by military aviation is the designation of air routes to carry out the AAR mission (Air to Air Refuelling). The road network should be designed in such a way that the refuelling mission can be carried out in any airspace in which the flight is carried out. Air routes assigned to AAR missions should combine to allow refuelling between countries in European airspace and to be planned in such a way that they do not adversely affect airspace efficiency and performance and reduce safety. Air routes should be organised in airspace with low air traffic and a low population density.

\section{Military aircraft flights in the airspace class $G$ at speeds of over $250 \mathrm{kt}$}

Polish airspace available for air navigation is divided into controlled (Class C) and uncontrolled (Class G) airspace, where the FIS (Flight Information Service) and unclassified space are provided. Class G space restrictions apply to the 250-speed limit ban.

\begin{tabular}{|l|l|l|l|l|l|l|}
\hline Class & $\begin{array}{l}\text { Type } \\
\text { of } \\
\text { flight }\end{array}$ & $\begin{array}{l}\text { Provided } \\
\text { service }\end{array}$ & $\begin{array}{l}\text { Provided } \\
\text { service }\end{array}$ & Speed limits & $\begin{array}{l}\text { Required radio } \\
\text { communication }\end{array}$ & $\begin{array}{l}\text { Necessity to } \\
\text { obtain ATC } \\
\text { permit }\end{array}$ \\
\hline \multirow{2}{*}{ G IFR } & Not assured & $\begin{array}{l}\text { Air } \\
\text { information } \\
\text { service }\end{array}$ & $\begin{array}{l}\text { 250 kt IAS } \\
\text { Less than 3 050 } \\
\text { m }(10,000 \mathrm{ft}) \\
\text { AMSL }\end{array}$ & $\begin{array}{l}\text { Continuous two } \\
\text { way }\end{array}$ & Not required \\
\cline { 2 - 6 } & VFR & Not assured & $\begin{array}{l}\text { Air } \\
\text { information } \\
\text { service }\end{array}$ & $\begin{array}{l}\text { 250 kt IAS } \\
\text { Less than 3 050 } \\
\text { m (10,000 ft }) \\
\text { AMSL }\end{array}$ & Not required & Not required \\
\hline
\end{tabular}

Table 1. Military aircraft flights in the airspace class $G$

It is proposed to change the flight rules in space $G$ in such a way as to create the possibility of tactical military aircraft (Grippes, MiG-29 or F-16) flying in Class G space at speeds exceeding $250 \mathrm{kt}$. 
Considering the equipment and technical capabilities of the aircraft (radar stations, anti-collision systems, avionics, and emergency exit systems), the admission of Class G military aircraft will not reduce the level of security for its users. Military aircraft crews will not operate in segregated airspace structures with the awareness that remaining air traffic must maintain a safe separation and will perform the flight according to VFR regulations. At the same time, there is a need to raise awareness among other users of this class of airspace of the possibility of encountering high-speed military missions, which will reduce the response time during flight maneuvers to bypass the aircraft operating on a collision course.

\section{Conclusions}

These solutions will allow "bottlenecks" in airways to be reduced; - increasing the efficiency of airspace use; improving the safety of air navigation in Central European airspace; providing air traffic services in all parts of the airspace; and military personnel obtaining a licence in accordance with aviation law. Furthermore, the introduction of the aforementioned changes will result in increased efficiency of airspace used, improve civil and military cooperation and increase security in Polish and Central European airspace.

\section{References}

Annex 11 to the Convention on International Civil Aviation. Air Traffic Services. Annex 15 to the Convention on International Civil Aviation. Air Information Services. Annex 2 to the Convention on International Civil Aviation. Air Traffic Regulations. Annex 20 to the Convention on International Civil Aviation. Safety Management. Doc 444 (ICAO). Air Traffic Management. International Civil Aviation Convention signed on 7 December 1944. (OJ of 26 June 1959). Rozporządzenie Ministra Infrastruktury z dnia 25 listopada 2008 r. w sprawie struktury polskiej przestrzeni powietrznej oraz szczegółowych warunków i sposobu korzystania z tej przestrzeni (DzU z 2008, Nr 210, poz. 1324).

Rozporządzenie Ministra Obrony Narodowej z dnia 5 stycznia 2005 r. w sprawie przekraczania granicy państwowej i lotów obcych wojskowych statków powietrznych w przestrzeni powietrznej Rzeczypospolitej Polskiej (DzU z 2005, nr 11, poz. 80). 
Ustawa z dnia 12 grudnia 1990 r. o ochronie granicy państwowej (DzU 2009, nr. 12, poz. 67).

Ustawa z dnia 3 lipca 2002 r. - Prawo lotnicze (DzU 2002, nr. 130, poz. 1112).

Ustawa z dnia 8 grudnia 2006 r. o Polskiej Agencji Żeglugi Powietrznej (DzU 2006 nr 249, poz. 1829). 